\title{
MENIERE'S DISEASE AND MIGRAINOUS VERTIGO: COULD WE DIFFERENTIATE THOSE USING OTONEUROLOGIC TESTS?
}

\author{
Panagiotis Gerbesiotis ${ }^{1,2}$, Pavlos Marangoudakis², Thomas Nikolopoulos ${ }^{2}$ \\ ${ }^{1}$ Department of Otorhinolaryngology, Head and Neck Surgery, Naval Hospital of Athens, Athens, Greece \\ ${ }^{2} 2^{\text {nd }}$ University Department of Otorhinolaryngology, Head and Neck Surgery, “ATTIKON” Hospital, Athens, \\ Greece
}

Corresponding author: Panagiotis Gerbesiotis, Department of Otorhinolaryngology, Head and Neck Surgery, Naval Hospital of Athens, 70 Deinokratous str., Postal code: 11521, Athens, Greece, mobile: +306936614580 , Hospital tel.: +302107261114, Hospital telefax number: +302107261175, e-mail: pgerbesiotis@yahoo.com

List of acronyms - abbreviations: EcochG - electrocochleography; cVEMP - cervical vestibular evoked myogenic potentials; VNG - videonystagmography; MD - Meniere’s Disease; CM - cochlear microphonics; SP - summating potentials; AP - action potentials; UW - unilateral weakness; DP - directional preponderance; ET - extratympanic.

The authors have no funding, financial relationships, or conflicts of interest to disclose.

\begin{abstract}
Background: The aim of this prospective study was to examine the link between Meniere's disease and migrainous vertigo and assess the value of common non-invasive otoneurologic tests in the differential diagnosis.

Material and Methods: A total of 38 patients with definite Meniere's disease (MD), 24 with non Meniere's vertigo, dizziness or unsteadiness (control group), and 10 patients with definite Vestibular Migraine (VM) underwent a full otoneurological screening which included an audiometric examination, extratympanic electrocochleography (ET - ECochG), cervical vestibular evoked myogenic potentials (cVEMPs) and videonystagmography with bithermal stimulation.
\end{abstract}

Results: None VM patient presented with abnormal ECochG finding, in contrary to $61 \%$ of MD patients, and $4 \%$ in the control group. The difference was statistically significant $(p<0.001)$. Pathological cVEMP results and unilateral weakness in caloric stimulation were found in $30 \%$ and $10 \%$ in VM population, whereas in $52.6 \%$ and $55.3 \%$ in MD. Again, the difference was statistically significant $(p<0.001)$.

Conclusions: The results indicate that certain vestibular test - as ECochG - could often help in the differentiation between VM and MD patients, especially in atypical cases. Last but not least, it seems that both diseases have a common electrophysiological background according to the similar cVEMP pathological findings.

Keywords: migrainous vertigo • Meniere's disease • electrocochleography • cVEMP • videonystagmography

\section{LA ENFERMEDAD DE MÉNIÈRE Y EL VÉRTIGO MIGRAÑOSO: ¿PODEMOS DIFERENCIARLOS CON AYUDA DE EXÁMENES OTONEUROLÓGICOS?}

\section{Resumen}

Introducción: El objetivo de los estudios prospectivos comentados era diagnosticar la relación entre la enfermedad de Ménière y el vértigo migrañoso y evaluar la utilidad de las pruebas otoneurológicas no invasivas ordinarias en el diagnóstico diferencial.

Material y método: El grupo estudiado se componía de 38 pacientes con enfermedad de Ménière diagnosticada, 24 pacientes con vértigo central no causado por la enfermedad de Ménière, con vértigo periférico o con trastornos del equilibrio (grupo de control), y 10 pacientes con vértigo migrañoso diagnosticado. A los pacientes se les hizo una revisión otoneurológica completa que comprendía: estudio audiométrico, electrococleografía extratimpánica (ET-ECochG), estudio de los potenciales miogénicos evocados vestibulares cervicales (cVEMPs) y videonistagmografía con estimulación bitérmica.

Resultados: No se constató en ningún paciente con vértigo migrañoso resultados anormales de la ECochG, frente a un $61 \%$ en el grupo de pacientes con la enfermedad de Ménière y un $4 \%$ en el grupo de control. Esta diferencia era estadísticamente significativa $(p<0.001)$. En la población de pacientes con vértigo migrañoso se constataron resultados patológicos de los cVEMP y un deterioro unilateral con la estimulación calórica respectivamente en el 30\% y el 10\% de los pacientes, mientras que en los 
pacientes con la enfermedad de Ménière estas cifras eran respectivamente del 53\% y el 55\%, lo que constituía una diferencia estadísticamente significativa $(p<0.001)$.

Conclusiones: Los resultados muestran que ciertas pruebas vestibulares (como la ECochG) pueden ser a menudo útiles en el diagnóstico diferencial de pacientes con vértigo migrañoso y enfermedad de Ménière, sobre todo en casos atípicos. Parece que ambas enfermedades se caracterizan por tener síntomas electrofisiológicos similares, lo que hace que se produzcan desviaciones de la norma en el ámbito de los cVEMP.

Palabras clave: vértigo migrañoso • enfermedad de Ménière • electrococleografía • cVEMP • videonistagmografía

\section{БОЛЕЗНЬ МЕНЬЕРА И МИГРЕНЕВОЕ ГОЛОВОКРУЖЕНИЕ: МОЖЕМ ЛИ МЫ ИХ РАЗЛИЧИТЬ С ПОМОЩЬЮ ОТОНЕВРОЛОГИЧЕСКИХ ИССЛЕДОВАНИЙ?}

\section{Изложение}

Введение: Цель обсуждаемых проспективных исследований - опознание связи между болезнью Меньера и мигреневым головокружением, а также оценка пригодности всеощих неинвазивных отоневрологических тестов в дифференциальной диагностике.

Материал и метод: Исследованная группа состояла из 38 пациентов с опознанной болезнью Меньера, 24 пациентов с системным головокружением, не вызванным болезнью Меньера, с несистемным головокружением или с нарушениями равновесия (контрольная группа) и 10 пациентов с опознанным мигреневым головокружением. У пациентов проведено полное отсеювающее отоневрологическое исследование, включающее в себя: аудиометрическое исследование, экстратимпанальную электрокохлеографию (ЕT-ECochG), исследование шейных вызванных вестибулярных миогенных потенциалов (cVEMPs) и видеонистагмографию с битермической стимуляцией.

Результаты: У ни одного из пациентов с мигреневым головокружением не обнаружено отклоняющихся от нормы результатов ECochG, в противоположность 61\% пациентам в группе с болезнью Меньера и $4 \%$ в контрольной группе. Эта разница была статистически значимой $(p<0.001)$. В популяции пациентов с мигреневым головокруженим обнаружили патологические результаты cVEMP и односторонее ослабление при калорической стимуляции, соответственно у $30 \%$ и $10 \%$ пациентов, тогда как у пациентов с болезнью Меньера эти цифры составили соответственно 53\% и 55\%, что было статистически значимой разницей $(p<0.001)$.

Итоги: Результаты показывают, что определенные вестибулярные тесты - такие как EcochG - могут быть зачастую полезными в дифференциальной диагностике пациентов с мигреневым головокружением и болезнью Меньера, особенно в атипических случаях. Кажется, что обе болезни характеризуются подобными электрофизиологическими симптомами, что приводит к наличию подобных отклонений от нормы в области cVEMP.

Ключевые слова: тигреневое головокржение • болезнь Меньера • электрокохлеография • cVEMP • видеонистагмография

\section{CHOROBA MENIERE'A A MIGRENOWE ZAWROTY GLOWY: CZY MOŻEMY JE ROZRÓŻNIĆ PRZY POMOCY BADAŃ OTONEUROLOGICZNYCH?}

\section{Streszczenie}

Wprowadzenie: Celem tego badania prospektywnego było zbadanie związku pomiędzy chorobą Meniere’a a migrenowymi zawrotami głowy i ocena przydatności powszechnych nieinwazyjnych testów otoneurologicznych dla rozpoznania różnicowego.

Materiał i metoda: Grupa złożona z 38 pacjentów z rozpoznaniem choroby Meniere’a, 24 pacjentów z układowymi zawrotami głowy nie spowodowanymi chorobą Meniere’a, z nieukładowymi zawrotami głowy lub z zaburzeniami równowagi (grupa kontrolna), oraz 10 pacjentów z rozpoznaniem migrenowych zawrotów głowy przeszła pełne przesiewowe badanie otoneurologiczne obejmujące: badanie audiometryczne, elektrokochleografię zewnątrzbębenkową (ET-ECochG), badanie szyjnych miogennych przedsionkowych potencjałów wywołanych (cVEMPs) oraz wideonystagmografię ze stymulacją bitermiczną.

Wyniki: U żadnego z pacjentów z migrenowymi zawrotami głowy nie stwierdzono odbiegających od normy wyników ECochG, w porównaniu do $61 \%$ w grupie pacjentów z choroba Meniere’a i $4 \%$ w grupie kontrolnej. Różnica ta była statystycznie istotna $(p<0,001)$. W populacji pacjentów z migrenowymi zawrotami głowy stwierdzono patologiczne wyniki cVEMP i jednostronne osłabienie przy stymulacji kalorycznej odpowiednio u 30\% i 10\% pacjentów, podczas gdy u pacjentów z chorobą Meniere’a odpowiednio liczby te wynosiły $53 \%$ i $55 \%$, co było statystycznie istotną różnicą $(p<0,001)$. 
Wnioski: Wyniki wskazują, że pewne testy przedsionkowe - takie jak ECochG - mogą być często przydatne przy rozpoznaniu różnicowym pacjentów z migrenowymi zawrotami głowy i chorobą Meniere’a, szczególnie w przypadkach nietypowych. Wydaje się, ze obie choroby mają wspólną elektrofizjologię powodując podobne odchylenia od normy w zakresie cVEMP.

Słowa kluczowe: migrenowe zawroty głowy • choroba Meniere’a • elektrokochleografia $\bullet$ cVEMP • wideonystagmografia

\section{Background}

As migrainous vertigo (MV) is an evolving entity, it is not surprising that terminology is confusing and that generally accepted diagnostic criteria are lacking. Various terms, including migraine - associated dizziness or vertigo, migraine - related vestibulopathy, vestibular migraine (VM), and basilar-type migraine, all have been applied to approximately the same patient population. On the other hand, dizziness and vertigo rank among the most common complaints in the general population and as a consequence they are often reported by patients who have migraine. In addition, there are several vestibular disorders that have been associated to migraine (coincidentally or not), including Meniere's disease (MD), Benign Paroxysmal Positional Vertigo (BPPV), motion sickness, and orthostatic hypotention [1].

The association between migraine and vertigo has been a matter of debate the last years. A central or peripheral vestibular damage may occur in patients with migrainous vertigo. In most patients, migraine begins earlier in life than MV. Some patients have been free from migraine attacks for years when MV first manifests itself. The latest version of the International Headache Society (HIS) classification include vestibular migraine in its appendix as an emerging disorder.

Migraine disorders can often mimic the symptoms of Meniere's disease. It would be of enormous help to clinicians if otoneurologic exams could distinguish Meniere's disease from migraine. Therefore, the aim of the present study is to assess extratympanic electrocochleography (ET - ECochG), cervical vestibular-evoked myogenic potentials (cVEMP), and videonystagmography (VNG) with caloric testing at the same examination day in both disorders to determine whether there might be an electrophysiological link or difference between these two disorders.

\section{Material and Methods}

The criteria for diagnosis of definite and probable migrainous vertigo are the following. Definite migrainous vertigo involves a history of episodic moderate vertigo, migraine, and at least one characteristic migraine symptom during two vertiginous attacks. Probable migrainous vertigo involves a history of episodic moderate vertigo with at least one of the following: migraine, migrainous symptoms during vertigo, migraine-specific vertigo triggers (such as foods, olfactory/visual stimuli, hormonal changes, and/or sleep disturbances), or response to anti-migraine therapy.

Regarding the clinical presentation, adults who have MV typically report spontaneous or positional vertigo. Head motion intolerance, similar to motion sickness is a frequent additional symptom [2]. Nausea and imbalance are frequent but nonspecific accompaniments of acute MV,as well of all vestibular disorders. The duration of vertigo ranges from a few seconds to several hours or, less frequently, even days; duration of a few minutes or of several hours is most frequent [3]. The attacks may occur days, months, or years apart in an irregular fashion. Along with the vertigo, patients may experience photophobia, phonophobia, osmophobia, or visual or other auras. These phenomena are of diagnostic importance, because they may represent the only apparent connection of vertigo and $\mathrm{mi}$ graine. Hearing loss and tinnitus are not prominent symptoms of $\mathrm{MV}$, but are reported in individual patients who have MV. Hearing loss usually is mild and transient, without progression in the course of the disorder. In a situation of diagnostic uncertainty, treatment can be tentatively directed to a certain disease. Moreover, typical migraine triggers include deficient or irregular sleep, excessive stress, and specific foods such as matured cheese, red wine and glutamate, sensory stimuli such as bright or scintillating lights, intense smells, and noise.

Meniere's syndrome is classically characterized by a quadrad of symptoms: aural fullness, fluctuating sensorineural hearing loss (SNHL), roaring tinnitus, and spinning vertigo, often accompanied by nausea and/or vomiting. It is an inner ear disorder whose pathological correlate is endolymphatic hydrops. The most common presentation involves only one ear. The incidence of bilateral involvement in published reports varies widely, between 2 and $78 \%$. The enormous range appears to reflect a lack of consensus about diagnostic criteria and varying lengths of time of follow-up [4,5]. Endolympatic hydrops is most consistently found in the pars inferior of the inner ear, that is, the cochlea and saccule, as bowing of the Reissner membrane out toward the scala vestibule and distention of the saccule. When saccular distention is extensive, it can distort the utricle and semi-circular canals in the vestibule and the saccular membrane can bulge out to contact the stapes footplate either directly or via fibrous adhensions. All these disorders can cause pathological findings in both ECochG and VEMP.

A total of 38 patients with definite Meniere's disease according to the criteria established by the 1995 American Academy of Otolaryngology, Head and Neck Surgery, Balance and Hearing Committee, 24 with non Meniere's vertigo, dizziness or unsteadiness (control group) and $10 \mathrm{pa}-$ tients with definite Vestibular Migraine were assessed in the Neurotology Department of our University Hospital. All subjects were evaluated with a detailed medical history, a full physical examination, and audiologic/neurotologic evaluation that included pure-tone audiometry, tympanometry, cVEMP, ET-ECochG, and VNG with caloric stimulation. The duration of the above performed tests per subject was approximately 1 hour and within a specific time frame (1-5 days) of the last acute episode of vertigo/dizziness. All the control group patients were matched in age with the VM and MD group. The choice 
Table 1. Average hearing loss of all subjects

\begin{tabular}{lcccc}
\hline Disease/group & $\mathbf{5 0 0 ~ H z}(\mathbf{d B})$ & $\mathbf{1 0 0 0 ~ H z}(\mathbf{d B})$ & $\mathbf{2 0 0 0 ~} \mathbf{~ z z}(\mathbf{d B})$ & $\mathbf{4 0 0 0 ~} \mathbf{~ z z}(\mathbf{d B})$ \\
\hline Definite Meniere's disease & 43.2 & 42.8 & 36.9 & 37.5 \\
\hline Definite Vestibular Migraine & 32.1 & 33.8 & 35.7 & 38.7 \\
\hline Control Group & 34.6 & 37.1 & 42.6 & 43.8 \\
\hline
\end{tabular}

of the patients was done in a way as not to have major difference in degree of hearing loss between them for comparable results. It is supported that the sensitivity of ECochG often increases as the hearing ability gets poorer at MD patients [6]. Thus, MD patients with severe hearing loss were excluded in order not to influence the final results. Additionally, it is quite possible for person with very poor hearing (especially high-frequency) to be no ECochG at all on the side of hearing loss. Futhermore, 3 of $10 \mathrm{VM}$ patients were over 59 years old with mild to moderate presbycusis and one with chronic acoustic trauma. The control group presented with normal and abnormal hearing ability due to different causes, but without MD characteristics (as fluctuating low-frequency hearing loss). According to some authors, migraine-associated low-frequency hearing loss is not uncommon, with the range of occurrence reported between $10 \%$ and $38 \%$ and is believed to be due to varius mechanisms $[7,8]$. As with the vestibular sensory epithelium, the cochlea is believed to be innervated by calcitonin gene-related peptide (CGRP) containing fibers. This may be the pathogenesis of migraine - related auditory symptoms, such as hearing loss and phonophobia. The average hearing loss of all patients and controls in the basic frequencies $0.5,1,2$, and $4 \mathrm{KHz}$ are illustrated in Table 1.

Sound-induced cervical vestibular-evoked myogenic potentials (cVEMPs) are used to investigate saccular function, measured from the tonically contracted sternocleidomastoid muscles (SCM) in response to loud sound stimuli. The aim of the present study was to assess cVEMPs in patients with vestibular migraine and definite $\mathrm{MD}$ and to mainly determine whether saccular function is affected by these diseases. The amplitude and latency of VEMPs were measured from the sternocleidomastoid muscle in 38 patients with Meniere's disease (median age 50 years, range $31-82$ years) and in 10 patients with vestibular migraine (median age 45 years, range $31-68$ years) and were compared to those of 24 , gender and age-matched, controls (median age 51 years, range $23-74$ years). The patients of the control group had dizziness or unsteadiness not meeting the criteria for either MD or VM. Clicks of $0.1 \mathrm{~ms}$ duration were presented at a rate of 5.1 per second through an insert earphone. The click intensities were $100 \mathrm{~dB}$, the EMG signal was amplified, and the bandpass was filtered $(20 \mathrm{~Hz}$ to $2 \mathrm{KHz})$. The analysis window was $100 \mathrm{~ms}$ wide. Responses to a total of 100-150 stimuli were averaged. The amplitude of the first positive - negative peak was analyzed, P1-N1 ipsilateral to the stimulated ear with latencies of $\mathrm{P} 1$ and N1. For the evaluation of amplitude, the percentage of cVEMP asymmetry (VA) was calculated as $100[(\mathrm{Au}-\mathrm{Aa}) /(\mathrm{Aa}+\mathrm{Au})]$, where $\mathrm{Au}$ is the P1-N1 amplitude on the unaffected side and Aa is the
P1-N1 amplitude on the affected side. We interpreted the cVEMP using our cVEMP response data recorded from healthy persons as the reference values. Latencies or VA above the upper limit of the normal value were interpreted as abnormal. An abnormal cVEMP is seen as a reduction in amplitude of $36 \%$ or greater. Furthermore, when we recorded an important deviation (approximately above 6-7 msec) to P1 and N1 latencies, we also considered the cVEMP response as abnormal.

Electrocochleography is a test of auditory evoked potentials, which comprises potentials with short latencies (up to $2 \mathrm{~ms}$ ). ECochG consists of three components: cochlear microphonics (CM), summating potentials (SPs), and compound action potentials (APs). The origin of CM and SPs is the cochlea, whereas APs derive from the cochlear nerve. It is widely accepted that the (negative) SPs of MD patients are significantly larger than those of healthy subjects. Such large SPs are thought to reflect distention of the basilar membrane due to endolymphatic hydrops. The ratio of the negative SPs to compound APs (CAPs) has been introduced as a parameter. The upper limit of the normal range of the ratio SPs/CAPs after click stimulation has been set at 0.50 . TipTrode electrodes coupled to a tubal insert phone were placed into the external ear canal that has been cleaned with alcohol-impregnated cotton swabs. The reference and the ground electrodes were placed at the contralateral mastoid process and the forehead, respectively. The repetitions of the signal were between $600-800$, the filter bandpass $5-3,000 \mathrm{~Hz}$ and the amplification gain 50,000-100,000. Presenting clicks in alternating polarity inhibits the presence of stimulus artifact and CM and broasts the SP wave. 100 microseconds is a popular choice for the duration of the rectangular pulse that produces the click. A signal rate of $7.1 / \mathrm{sec}$ enhances both SP and AP component. In addition, the SP is better detected at a click intensity level of about $95 \mathrm{~dB} \mathrm{HL}$ [9]. Each average was replicated at least two times. At extratympanic (ET) ECochG we prefer to measure the "absolute" or peak - to peak amplitudes of the SP and AP as opposed to using a baseline reference. The reason for this choice relates to the considerable fluctuation of the baseline amplitude obtained with ET recordings. The main technical problem plaguing ECochG is noise. We also used this electrophysiological exam in patients with VM and the control group in order to analyze the findings.

Parallel, VNG caloric testing was conducted to test whether deficits in the various tests are associated with each other. Abnormal findings, according to our normative data, were considered when a unilateral weakness (UW) was found above $22 \%$ and when a directional preponderance (DP) was above $28 \%$. 
Generally, in all patients, including those with bilateral MD ( 7 of 38 patients $-18.4 \%$ ), we analyzed the data from the ear with the worst auditory capacity or/and symptoms, such as aural fullness and tinnitus. An informed consent was not obligatory from the patients, as the above exams have been in daily common laboratory practice of our hospital.

\section{Data analysis}

All the above tests took place for each patient at the same examination day at the neurotology laboratory of our department by the same examiner (first author), in order to achieve similar circumstances.

The statistical methods used in the present study were the $\chi^{2}$ test for abnormal rates among disease entities and analysis of parameters, and the one - way ANOVA test to compare the values of parameters. The significant statistical difference was set at $p<0.05$. The sensitivity and specificity were also calculated.

\section{Results}

In comparison to the controls, 20 of the 38 patients with Meniere's disease (52.6\%), and 3 of the 10 patients with vestibular migraine (30\%) had pathological electromyography - corrected cVEMP results. More specifically, among the 3 patients with VM with abnormal cVEMP, 2 had absent cVEMPs on the affected side (with the worst auditory capacity or/and audiological symptoms) and 1 patient showed decreased VEMP amplitude. The mean of the P1$\mathrm{N} 1$ amplitudes of the last vestibular migraine patients was 1.23 (SE \pm 0.09 ) for the right and 1.22 ( $\mathrm{SE} \pm 0.09$ ) for the left side, whereas the averaged amplitudes of the 24 controls showed a mean of 1.81 ( $\mathrm{SE} \pm 0.09$ ) on the right and of 1.79 ( $\mathrm{SE} \pm 0.09$ ) on the left. No statistically important difference was seen in the latencies between MV and CG. Although MD patients showed absent $(n=13)$ or decreased cVEMPs $(n=4)$, they rarely displayed delayed peaks $(n=3)$. The unique patient of the control group with abnormal cVEMP results presented increased latencies (Figure 1, dark grey column).

The abnormal electrocochleographic rates were $62.16 \%$, $0 \%$ and $4,17 \%$ in the definite $\mathrm{MD}$, definite VM and control group, respectively. These differences were statistically significant $(p<0.001)$ (Figure 2 , dark grey column). There were also statistically significant differences with regard to the mean SP/AP ratios in these groups: the average values were $0.63,0.24$, and 0.29 in the definite MD, VM and control group, respectively. The mean value and the standard deviation of AP latency were $1.32 \pm 0.11,1.31 \pm 0.12$, $1.27 \pm 0.11$, respectively (no statistically significant difference). Last, but not least, the mean values for SP and AP amplitude were $0.12,0.08,0.09$ and $0.31,0.26 \& 0.28 \mathrm{mV}$ in the definite MD, VM and control group (no statistically significant difference).

Approximately $10 \%$ of patients with VM had unilateral hypoexcitability to caloric stimulation and directional preponderance of nystagmus responces. More often, findings during acute MV pointed to central and not to peripheral vestibular dysfunction. Pathological nystagmus at VM

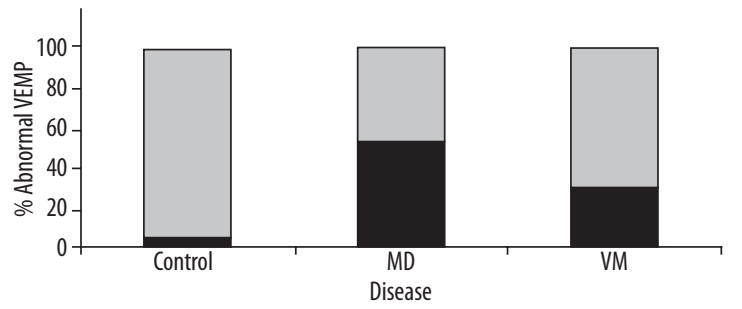

Figure 1. Diagram showing abnormal CVEMP values by disease. (light grey: normal CVEMP, dark grey: abnormal cVEMP). cVEMP - cervical Vestibular Evoked Myogenic Potentials, MD - Meniere's disease, VM - Vestibular Migraine

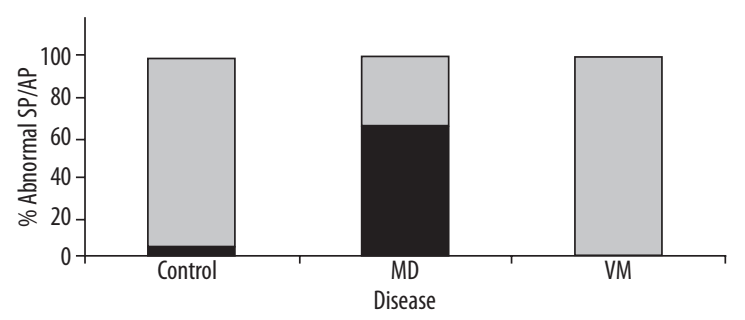

Figure 2. Diagram showing abnormal SP/AP ratio by disease. (light grey: normal SP/AP ratio, dark grey: abnormal SP/AP ratio). SP - Summating Potentials, AP - Action Potentials, MD Meniere's Disease, VM - Vestibular Migraine

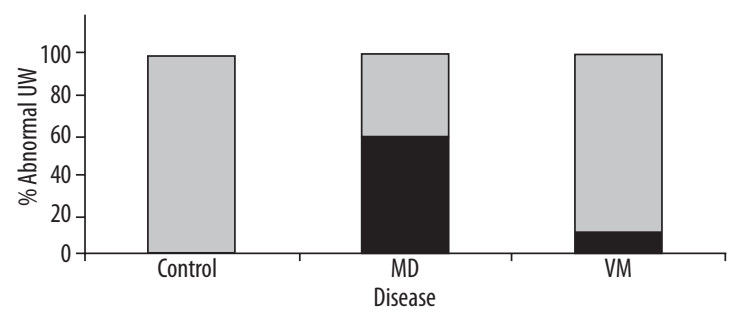

Figure 3. Diagram showing abnormal UW by disease. (light grey: normal UW, dark grey: abnormal UW). UW - Unilateral Weakness, MD Meniere's Disease, VM - Vestibular Migraine

patients was observed in 40\%: two had isolated spontaneous nystagmus, one had isolated positional nystagmus and one had a combination of the two. Three patients showed signs of central brainstem or cerebellar disorders for altered pursuit or saccades or positional direction changing nystagmus. On the other hand, 21 of the $38 \mathrm{MD}$ patients (55.3\%) presented with unilateral weakness (Figure 3, dark grey column) and 8 (21\%) with directional preponderance. To sum up, there is a statistically important difference in the results of caloric stimulation between these two diseases $(p<0.001)$.

The prevalence of migraine according to our survey was almost twice as high in the MD group than in the control group ( $40 \%$ versus $17 \%, p<0.001$ ). Furthermore, $32 \%$ of the patients who had MD always experienced at least one migrainous symptom (mainly headache, photophobia, 
phonophobia, or more seldom aura symptoms) along with their MD attacks. The study illustrates that there are patients who have migraine and recurrent vertigo for whom it is not possible to differentiate with certainty if they have MV or MD. The two conditions may share pathophysiologic mechanisms that lead to a spectrum of migrainous, vertiginous, and cochlear symptoms.

\section{Discussion}

The diagnosis of Meniere's syndrome or disease is supposed to be made clinically, based on the four characteristic symptoms in the patient's history. However, in real life, symptoms are not always classic or well described. Moreover, symptoms need not be (and frequently are not) present simultaneously or in the same pattern, especially in the early phases of the disease. In a survey of neuro-otologists [10], only one third relied solely on history, physical examination and audiometry, despite the recommendation of the AAO-HNS Committee on Hearing and Equilibrium [11]. Two thirds used adjunctive tests, which include electrocochleography (ECochG), electro- or videonystagmography (ENG or VNG), rotary chair evaluation, vestibular-evoked myogenic potentials (VEMPs), glycerol and furosemide dehydration tests, posturography, auditory brainstem response ( $\mathrm{ABR}$ ) testing, tympanometry, blood tests, and imaging.

The present study suggests that ECochG (which indicates the presence of endolymphatic hydrops) is useful in the differential diagnosis between MD and MV patients in approximately $60 \%$. This could be very important, especially in atypical cases. Moreover, performing caloric testing in 5 days from the acute episode, it is more likely to find positive results in MD (55\%) than VM (10\%) patients. Last but not least, we should take into account that more than half of the MD patients have pathological cVEMP (53\%) in comparison to the lower percentage $40 \%$ of the VM patients. According to another survey, approximately $68 \%$ of VM patients had reduced EMG-corrected VEMP amplitudes compared to the controls [12]. Thus, these outcomes provide evidence that mainly the saccule may be affected in both disorders, indicating a possibly labyrinthine related cause for the pathogenesis of both vestibular migraine and Meniere's disease.

Like migraine itself, MV is supposed to be diagnosed not by specific laboratory/biologic markers, but on the basis of specific history. In accordance with most investigators, the proposed criteria conceptualize MV as an episodic vestibular disorder. The distinction between vertigo (which is a vestibular symptom) and dizziness usually can be made by careful history taking: rotational vertigo or other illusory sensations of motion indicate vertigo, whereas a sensation of light-headedness, giddiness, drowsiness, or impending faint suggests often dizziness of nonvestibular origin. However, recent research has cast some doubts on this traditional distinction and teaching [13]. The clinical association of migraine and vertigo has been supported by case-controlled studies showing that migraine is more common in patients presenting with dizziness than in age- and sex-matched controls and inversely, that vertigo is more common in patients with migraine than in controls [14]. However, the pathophysiology of MV is still a matter of speculation and it is not known to what extent the dysfunction is located in the central or peripheral vestibular system.

Sporadic accounts of headaches as an additional symptom in typical Meniere's attacks suggested a link between $\mathrm{MD}$ and migraine. Subsequent studies of the prevalence of migraine in MD produced conflicting results, but a recent controlled study provides well-documented evidence in favor of such an association [15]. Atypical Meniere's disease includes cochlear hydrops or vestibular hydrops. In the first one, there is aural fullness, tinnitus and fluctuating SNHL without vertigo and in the second one there is episodic vertigo alone and attacks that occur without the typical low - frequency and fluctuating SNHL. Particular attention must be paid in bilateral cases to exclude autoimmunity, allergic Meniere's Disease, and otosyphilis. According to a study, the prevalence of migraine was found to be only $22 \%$ in patients with classic Meniere's disease, but $81 \%$ in patients with (atypical) vestibular Meniere's disease [16]. In a more recent study, $56 \%$ prevalence of migraine was found among patients with Meniere's disease [15], as defined by the 1995 guidelines. As a rule of thumb, hearing loss is usually an occasional, mild, and nonprogressive feature of migrainous vertigo [17], while it is a regular accompaniment of Meniere's disease progressing to severe hearing loss within a few or more years. However, in the Meniere's patient with a history of migraine, we should consider anti-migraine medication as part of the treatment options.

\section{Conclusions}

In summary, the clinical presentation of MV can be very atypical and the connection to migraine subtle or difficult. The key to the diagnosis is the repeated concurrence of migrainous symptoms and vertigo, migraine specific precipitants, and, sometimes, response to antimigraine drugs. In clinical practice, history usually provides more clues for the diagnosis than vestibular testing, because there are no abnormalities that are specific for MV. Vestibular testing, however, can be useful to reassure doctors that there is no severe abnormality, such as a complete canal paresis, which suggests another diagnosis. In addition, ECochG could often help the differentiation between MD and VM patients, mainly when there are atypical characteristics.

Characterizations of the signs and symptoms of "vestibular migraine" and of Meniere's disease often seem to overlap, suggesting that both diseases might be associated to a common peripheral vestibular dysfunction. This is further supported by the common cVEMP abnormalities.

\section{References:}

1. Neuhauser H, Lempert T. Vertigo and dizziness related to migraine: a diagnostic challenge. Cephalalgia, 2004; 24: 83-91.
2. Baloh RW. Neurotology of migraine. Headache, 1997; 37 : 615-21. 
3. Cutrer F, Baloh R. Migraine-associated dizziness. Headache, 1992; 32: 300-4.

4. Katsarkas A. Hearing loss and vestibular dysfunction in Meniere's disease. Acta Otolaryngol, 1996; 116: 185-88.

5. Green JD Jr, Blum DJ, Harner SG. Longitudinal followup of patients with Meniere's disease. Otolaryngol Head Neck Surg, 1991; 104: 783-88.

6. Conlon BJ, Gibson WP. Electrocochleography in the diagnosis of Meniere's disease. Acta Otolaryngol, 2000; 120: 480-83.

7. Cass SP, Furman JM, Ankerstjerne K, Balaban C, Yetiser S, Aydogan B. Migraine-related vestibulopathy. Ann Otol Rhinol Laryngol, 1997; 106: 182-89.

8. Lee H, Lopez I, Ishiyama A, Baloh RW. Can migraine damage the inner ear? Arch Neurol, 2000; 57: 1631-34.

9. Ferraro J, Best LG, Arenberg IK. The use of electrocochleoraphy in the diagnosis, assessment, and monitoring of endolymphatic hydrops. Otolaryngol Clin North Am, 1983; 16: 69-82.

10. Kim HH, Wiet RJ, Battista RA. Trends in the diagnosis and the management of Meniere's disease: results of a survey. Otolaryngol Head Neck Surg, 2005; 132: 722-26
11. Committee on Hearing and Equilibrium guidelines for the diagnosis and evaluation of therapy in Meniere's disease. American Academy of Otolaryngology-Head and Neck Foundation, Inc. Otolaryngol Head Neck Surg, 1995; 113: 181-85.

12. Baier B, Stieber N, Dieterich M. Vestibular-evoked myogenic potentials in vestibular migraine. J Neurol, 2009; 256: 1447-54.

13. Lempert T, Olesen J, Furman J et al. Vestibular migraine: diagnostic criteria. J Vestib Res, 2012; 22: 167-72.

14. von Brevern M, Neuhauser H. Epidemiological evidence for a link between vertigo and migraine. J Vestib Res, 2011; 21: 299-304.

15. Radtke A, Lempert T, Gresty MA, Brookes GB, Bronstein AM, Neuhauser H. Migraine and Meniere's disease: is there a link? Neurology, 2002; 59: 1700-4.

16. Rassekh $\mathrm{CH}$, Harker LA. The prevalence of migraine in Meniere's disease. Laryngoscope, 1992; 102: 135-38.

17. von Brevern $M$, Zeise D, Neuhauser H, Clarke AH, Lempert T. Acute migrainous vertigo: clinical and oculographic findings. Brain, 2005; 128: 365-74. 